\title{
Sustainable Zakat Accounting in Malaysia: An Analysis
}

\author{
Dr. Zahri Hamat \\ Centre for Islamic Development Management Studies Islam (ISDEV) \\ School of Social Sciences, Universiti Sains Malaysia \\ 11800 Minden, Pulau Pinang \\ E-mail : zahri@usm.my
}

DOI:10.5901/mjss.2014.v5n19p139

\begin{abstract}
This paper aims to identify and analyze sustainable zakat accounting as practiced by zakat institutions as well as the opinions of the scholars of zakat on sustainable zakat accounting. Based on content analysis, the findings showed there are practices of sustainable zakat accounting in zakat institutions in Malaysia. This includes first, the broadening of assets which are made compulsory for zakat; second, the assessment based on net assets; and third, changes in the assessment method of assets required for zakat. Sustainable zakat accounting is also supported by the scholars of zakat in Malaysia. It is argued that the foundations used in developing zakat accounting for assets which are non-unanimously agreed upon are based on the method of qiyas (analogy). As such sustainable zakat accounting will continue to be used due to its suitability with the demands of current needs and local circumstances.
\end{abstract}

Keyword: zakat accounting, sustainable, zakatable assets, income

\section{Introduction}

Zakat accounting means the process of identifying assets that are required for zakat, determine the conditions of assets that necessitates obligatory zakat, ascertaining the applicable zakat rates and calculating the assessment of zakat on the related assets. ${ }^{1}$ In the meantime, sustainable zakat accounting means zakat accounting that always take into account the current needs and local circumstances in determining zakat of a particular asset. Sustainable accounting is not something new. It has been practiced since the time of Khulafa 'al-Rashidun. Sustainable zakat accounting is expected to take place on an ongoing basis. Sheikh Mahmud Syaltut, former Shaykh al-Azhar for example, said that this is due to the differences of opinions among jurists on the types of asset that necessitate the imposition of obligatory zakat (Muhammad Abdul Mun'im Al-Jammal, 2000).

Generally, jurists divide the assets that necessitate obligatory zakat into two categories. First, are the unanimously agreed zakatable assets such as gold, silver, agriculture, livestock and business; Second, are the non-unanimously agreed zakatable assets such as income from employment and consultation services, stock investments and manufacturing. These non-unanimously agreed zakatable assets can change from time to time. In fact the people in Malaysia respond well enough on the imposition of zakat on these non-unanimously agreed zakatable assets. Table 1 displays the said assets which can be divided into four categories. First, the income; second, agricultural products; third, poultry; and fourth, minerals.

\footnotetext{
1 Zakat accounting in Arabic is termed as muhasabah al-zakah. Zakat accounting actually involves five stages. First, determine the assets that necessitates for zakat. Second, evaluate the assets that are necessitates compulsory zakat. Third, determine the appropriate rate of zakat. Fourth, the collection of the zakat from zakat payers and distribute the zakat to its recipients. Fifth, provide a report to the authorities about the collection and distribution of zakat.
} 
Table 1 Non-unanimously Agreed Zakat Assets

\begin{tabular}{ll}
\hline $\begin{array}{l}\text { Categories of Assets } \\
\text { Income }\end{array}$ & $\begin{array}{l}\text { Types of Assets } \\
\text { Salary, open income, shares, bonds, gifts, royalties, honorarium, } \\
\text { consultations and al-mustaghallat. } \\
\text { Agriculture }\end{array}$ \\
Pivestock & Chickens, ducks, fish, birds, ostriches and rabbits. \\
Minerals & Tin, iron pieces, gems and petroleum. \\
\hline
\end{tabular}

Source: Sanep Hairunnizam Ahmad \& Wahid (2003)

This paper intends to explore zakat accounting practices of zakat institutions in Malaysia and then explore the opinions of scholars of zakat towards sustainable zakat accounting that is practiced in Malaysia. It is divided into three parts. The first part identifies the basics of zakat accounting before exploring the sustainable zakat accounting practiced by the Khulafa 'al-Rashidun. It provides the background to this paper. The second part analyzes the broadening of assets that necessitate obligatory zakat, calculating the assessment of zakat based on the net asset, and the method of determining the rate of zakat assessment. It is meant to showcase the advent of sustainable zakat accounting of zakat institutions in Malaysia. The third part analyzes the opinions of scholars of zakat in Malaysia on sustainable zakat accounting in Malaysia, particularly the zakat accounting for income and business.

\section{Sustainable Zakat Accounting and Practices of The Khulafa 'Al-Rashidun}

The basis of sustainable zakat accounting is actually sourced from the Quran and the Sunnah of the Prophet Muhammad (pbuh) himself. ${ }^{1}$ It is as a result of the mentioning of the word assets in which zakat is compulsory to be imposed upon in two forms by the Quran and the Sunnah of the Prophet (pbuh). First is in the general form; and the second is in the specific form (Mahmood Zuhdi Abdul. Majid, 2003). In the general form, the Qur'an only mentions one part of the assets (wealth) (al-Tawbah, 9: 103) or assets (properties) (al-Dhariyat, 51: 19). In the specific form, the Quran mentions about gold and silver (al-Tawbah, 9: 34), agriculture (al-An'am, 6: 141), business and mineral resources (al-Baqarah, 2: 267).

According to Mahmood Zuhdi Abdul Majid (2003), although the Qur'an mentions specifically certain types of asset in which zakat is compulsorily imposed on them (al-Tawbah, 9: 34; al-An'am, 6: 141, and al-Baqarah, 2: 267), but there is no indication that restricts the general sense that is found in verse 103 of Surat al-Tawbah and verse 19 of Surat al-Dhariyat. According to him, these three verses describe only certain types of asset in which zakat is to be compulsorily imposed but this does not mean that for other types of assets zakat is not obligatory.

In the general form, the Prophet mentions the word "their wealth" (al-Bukhari, No. 478). While in the specific form, the Prophet mentions the types of wealth such as business assets (Abu Dawud, No. 1557), agricultural products such as wheat, barley and vines, livestock such as sheep (Al-Bukhari, No. 525), camel (al- Bukhari, No. 533), and mineral resources (AlBukhari, No. 575). The Prophet also mentioned the conditions in which it is obligatory to impose zakat on the wealth such as sufficient nisab (the passage one year) which bears the following meaning:-

"No zakat is imposed on less than five camels, and no zakat is imposed on silver that is less than five silver awaq, and no zakat is imposed on grains if less than five awsuq" (al-Bukhari, No.538).

Furthermore sustainable zakat accounting has also been detected from the writings of classical scholars. Among them is Abu Ubayd (1991). Abu Ubayd has compiled the Hadiths concerning the types of assets in which obligatory zakat is to be imposed upon them. He also made a review and then gave an opinion on an issue pertaining to the imposition of zakat on the assets or wealth in which zakat is compulsory to be imposed based on the Hadith of Prophet (pbuh) and opinions of jurists.

\footnotetext{
${ }^{1}$ The word wealth is a translation from the Arabic word amwal. The word amwal can also be translated as assets. For example, Allah says in the Quran: "Take (part) of the wealth (amwal) they become alms (zakat), (to him) you would cleanse them (of sin) and purifying them (from the bad manners) ..." (al-Tawbah, 9: 103).
} 
Among the writings of contemporary scholars about sustainable zakat accounting is Muhammad Kamal 'Atiyah (1995). Muhammad Kamal 'Atiyah concluded that assets in which zakat are to be compulsorily imposed can be divided into two categories. First, fixed assets; and second, current assets. ${ }^{1}$ Fixed assets are subject to zakat based on the income derived from the assets only while current assets are subject to zakat on both the assets and income derived from the assets. Al Yasa 'Abubakar (2009) on the other hand, concluded that assets or wealth in which zakat is compulsorily imposed can be divided into two categories. First, assets in possessions (treasures), such as gold, silver and livestock. Second, income such as agriculture, mineral resources and salary.

If this is the case, then this proves that sustainable zakat accounting will continue to be applicable. In fact the reign of the Khulafa' al-Rasyidin exhibited such a stand. ${ }^{2}$ Sustainability can at the very least be divided into three categories (Zahri Hamat, 2006). First, the government may reassess the property in which zakat is to be compulsorily imposed to suit current needs and local circumstances. Caliph 'Umar al-Khattab imposed zakat on horses, although, in the days of Prophet (pbuh) horses were exempted from zakat ('Ali Muhammad as-Sallabi, 2007). In contrast, during the caliphate of Ali b. Abi Talib, the horses were not subject to the imposition of zakat. ${ }^{3}$

Second, the government can broaden the basis of the imposition of zakat on a newly found asset or newly existed in society. Caliph 'Umar al-Khattab for example broaden the basis of zakat for livestock by imposing zakat on horses and the basis of zakat for agriculture by imposing zakat on peanuts, cotton and olives, as well as a few types of sea produce.

Third, the government can make changes to zakat accounting that is being practiced. Caliph 'Umar al-Khattab imposed zakat on honey at a rate of $5-10$ per cent based on the energy used in processing honey. Caliph Uthman $b$. Affan on the other hand imposed zakat on net assets. Zakat is assessed after deducting all the debts of the zakat payer first. Zakat is then imposed on the remaining asset or net asset. Caliph Ali b. Abi Talib, for example introduced the zakat rate for the first five camels, which can be replaced with a younger camel or an older one provided that compensation is paid to its owner with two sheep or 10 dirhams.

Sustainable zakat accounting occurs among others due to the mentioning of assets or wealth in which zakat is to be compulsorily imposed by the Qur'an and the Sunnah of Prophet (pbuh) himself either in general or in the specific sense. Sustainability is very much alive during the reign of the Khulafa' al-Rasyidun, specifically during the reign of Caliph 'Umar al-Khattab. The government then had re-evaluated the assets in accordance with the needs and local circumstances of the time. The government extended the basis of zakat by imposing zakat on new assets in the community. In fact changes in zakat accounting which was practiced then were also made.

\section{Sustainable Zakat Accounting and Practices of Zakat Institutions in Malaysia}

At the federal level, sustainable zakat accounting directly involves the Department of Islamic Development Malaysia (JAKIM). Among others JAKIM published a handbook on zakat in 2001. This handbook showcased the sustainability in zakat accounting. In fact the changes contained in the handbook are so great specifically on zakat accounting. Experts in the fields of Shariah, accounting and other professionals were involved in publishing this zakat handbook (JAKIM, 2001). The discussions in this handbook can be divided into three categories. First, zakat is only applicable to a particular asset. It covers zakat of gold and silver. Second, zakat is imposed on asset and the income derived from the asset. It covers the zakat on animals and zakat on business. Third, zakat is imposed only on the income derived from the asset. It covers zakat of agriculture, zakat ma'adin, kunuz and rikaz (buried treasure), as well as zakat of self-income. ${ }^{4}$ This handbook was republished by the Department of Awqaf, Zakat and Hajj (JAWHAR) in 2008 with the title Manual Pengurusan Pengiraan Zakat (Manual of Zakat Calculation Management).

\footnotetext{
1 The obligatory zakat on assets are in two categories that is tangible assets and intangible assets. Tangible assets are assets that cannot be concealed to avoid zakat such as agriculture, cattle and so on. Intangible assets are assets that can be hidden to avoid zakat, such as gold, silver and business commodities.

2 Reported by Abu "Ubayd which bears the following meaning: "One day, "Umar al-Khattab past the Himas, and said:" O Himas, pay zakat of your wealth. "Himas said:" I do not have anything other than arrows and a few strands of leather. "Then "Umar said: "Determine the price of the goods and then pay zakat" (Abu 'Ubayd, 1991: 362).

${ }^{3}$ Changes in the zakat rulings happened because the meaning and purpose of breeding horses had changed. During Caliph 'Umar alKhattab's time, horses were bred for commercial purposes, but during the time of Caliph Ali b. Abi Talib, horses were bred for the purpose of transportation and plowing.

4 Obligatory zakat for assets can be divided into eight types. One is gold and silver; second is business; third is livestock; fourth of agricultural products; fifth is the money; sixth ma'adin, kunuz and extractive; seventh stocks and bonds; and the eighth is the income (JAKIM, 2001).
} 
For zakat institutions in Malaysia, sustainable zakat accounting can at least be divided into three categories. First, the broadening of assets, wealth or properties subjected to obligatory zakat. It is an essential component of sustainable zakat accounting adopted by the institutions of zakat in Malaysia. Second, the assessment of zakat is based on net income or net asset. This means that zakat is imposed after deducting basic needs expenses of the zakat payers and their families. Third, is the sustainability of zakat accounting regarding the methods of interpreting obligatory zakat. It is used to assess assets in the two categories which are the unanimously agreed zakatable assets and the non-unanimously agreed zakatable assets.

Some of the significant broadening of assets or wealth on which zakat is compulsorily imposed is the zakat on income. Income is imposed as obligatory zakat based on the decision of the 31 ${ }^{\text {st }}$ Muzakarah Jawatankuasa Fatwa Kebangsaan (the $13^{\text {th }}$ Dialogue of the National Fatwa Committee) held on December 9, 1992. This was followed with Special Muzakarah Jawatankuasa Fatwa Kebangsaan which met on June 22, 1997.

It is also made as obligatory zakat by several State Islamic Religious Councils through the States Fatwa Committees. ${ }^{1}$ The Islamic Religious Council and Malay Customs of Kelantan (MAIK) requires zakat on employment income earned from work in the form of salaries, allowances, gratuities, compensation or income transfers or acquired through career oriented professionals, expertise or skills (Kelantan State Mufti Department, 1999). The Islamic Religious Council of Sarawak (MAIS) also imposes obligatory zakat on salaries, arrears of salaries, allowances and other income related to income after deducting basic needs, work financing, debts and any financing that is the cause to the real reason a person takes financing when the nisab (a minimum amount) is reached then zakat is to be imposed (State Fatwa Committee of Sarawak, 1996).

However, this differs from the Perak Syariah Committee's decision. This is because the salary or income is included in the category of obligatory zakat when nisab and haul (the passage of one year) have been reached as a condition that was ittifaq (consensus) by the majority of scholars in the four schools of thoughts. This requirement does not occur to salaries or income, thus there is no zakat imposed on salary or income (Perak Syariah Committee, 1990). ${ }^{2}$

Income means revenue received which incorporates employment income and open income. Employment income is the reward of a service with the employer covering the annual salary, arrears of salary, allowances and other income related to employment. Open income is an income through a job or business or expertise that is in the form of reward for the service rendered. This type of income includes legal services, counseling, consultation, health care, engineering, the arts and others (JAWHAR, 2008). ${ }^{3}$

In addition to income, the contributions or savings with the Employees Provident Fund (EPF) falls under the category of assets or properties that is not unanimously agreed upon. The National Fatwa Committee in November 1982 imposed compulsory zakat on EPF. The Selangor State also imposes obligatory zakat on EPF (Selangor Fatwa Committee, 2000). Assessment is made by two methods. First, zakat must be issued on the day the EPF contribution is received at a rate of 2.5 percent. Second, zakat must be issued when a haul (time frame) of one year has been reached after its receipt at the rate of 2.5 per cent (JAWHAR, 2008).

Holdings and investments in stocks and bonds are obligatory for zakat (JAWHAR, 2008). Perlis for example imposed compulsory zakat on stock trading activities (Perlis State Syariah Committee, 1988). Zakat is also imposed on sukuk and bonds holders (Melaka State Fatwa Committee, 2002). Owners of shares and sukuk are obliged to issue zakat if the company does not pay zakat on behalf of the owner of such shares. For shares owned after the haul is reached the rate imposed is at 2.5 per cent on the lower price between the market price and the purchase price. For stocks traded throughout

\footnotetext{
1 The broadening of assets which in turn contributes to substantial zakat collection is the income received by the individual Muslim. Lembaga Zakat Selngor in 2012 for example zakat collection for income is RM268.8 million (58\%) of the total collection of zakat of RM451.3 million.

2 Committee for each state in Malaysia are as follows: Perlis State Shariah Committee, Fatwa Committee of Kedah, Penang State Fatwa Committee, the Perak State Shariah Committee, Selangor State Fatwa Committee, Federal Territory Islamic Law Consultative Committee, Negeri Sembilan State Fatwa Committee, Melaka State Fatwa Committee, Johor State Fatwa Committee, Terengganu State Fatwa Committee, Board of Ulama' (Scholars) of the Islamic Religious Council and Malay Custom, Kelantan, Sabah State Fatwa Council, and Members of the Fatwa Board of the Sarawak State.

3 Perlis State Shariah Committee categorized zakat from income based on two types of qiyas (analogy). The first is analogous to the zakat of agriculture based on the acquisition at a certain time. The second is analogous to the zakat of gold and silver. It subscribes to the ground that obtained from an employee's salary that is it based on the value of gold as if what is available is gold. Therefore zakat from income is deemed as analogous to zakat of gold and silver.
} 
the haul, zakat is imposed at a rate of 2.5 per cent on the sale of shares after deducting the cost of purchasing the said shares (JAWHAR, 2008).

Statutory body which carries on business such as the Federal Land Development Authority (FELDA) zakat is compulsorily imposed on its business income (National Fatwa Committee, 2005). For the income of FELDA subsidiaries managed through separate accounts, the subsidiaries are required to pay zakat on the subsidiaries' revenues separately.

Zakat is assessed based on the net income after deducting the daruriyah expenses. Daruriyah expenses are the daily basic needs based on current expenses. Daruriyah expenses is an ijtihadi (legal reasoning) issue (Perlis State Shariah Committee). It is guided by the opinion of Ibn 'Abbas and Ibn' Umar. They agreed that the daruriyah expenses should be deducted prior to the payment of zakat. The opinion is supported by Ahmad b. Hanbal. ${ }^{1}$

In Kelantan the established rate for daruriyah expenses must be the most moderate for one year. The rates cover personal expenses and that of their families. Thus the rate for personal expenses is at RM5,000, expenses for wife at RM3,000 and expenses for children at RM2,000. These rates act as a general guide only because actual daruriyah expenses rate depends on the number of liabilities and other daruriyah expenses such as groceries and food, education, transportation costs and so on (Kelantan State Mufti Department, 1999). Selangor allow personal expenses of RM8,000 while for kids is RM1,000 per child (Selangor State Fatwa Committee). Perlis Mufti Department allows personal expenses of RM8,000, for a wife who does not work at RM5,000.00, while for the parents is the actual expenses. This daruriyah expenses generally include personal expenses, spouse, children, parents and other responsibilities such as brothers, sisters, neighbours and travellers (guests). Daruriyah expenses also include obligatory contributions such as EPF contribution. The zakat rate is 2.5 percent on the net income (JAWHAR, 2008).

Zakat institutions in Malaysia have been practicing sustainability in zakat accounting for some time. Business zakat accounting have been practiced by such institutions can be divided into three methods. First, zakat applies only to current assets $^{2}$ as practiced in the state of Kedah, Johor and Kelantan. Secondly, zakat is imposed on the working capital assets as practiced in Perlis. ${ }^{3}$ Third, zakat is imposed on the adjusted working capital as practiced in states other than the states of Kedah, Johor, Kelantan and Perlis. However at this point, all states in Malaysia impose zakat on the adjusted working capital.

Adjusted working capital means the adjustments made on current assets and liabilities appearing in the financial statements. These are some of the examples that exhibit the significance of sustainable zakat accounting for business. Adjustments that need to be made is first, the issue of the current asset items such as goods and haram (non-permissible) proceeds, deposits for utilities such as water, electricity and telephone and others as these items do not meet the conditions of perfect ownership; money borrowed because of the inability to fulfill the conditions of full or perfect ownership, the value of dividends in which zakat has been paid by the investing company; bad and expired stocks; contribution to funds of charitable nature; and stocks of raw materials as well as work-in-progress. Second, the adjusted current assets deduct current liabilities that are operating in nature such as trade payables and operational costs such as salaries, electricity, telephone and tax (JAWHAR, 2008).

There is also sustainable zakat accounting in zakat for agriculture. In Selangor, zakat for rice farming is charged at 5 per cent of the gross income (Selangor State Fatwa Committee). In the state of Terengganu, however, zakat is imposed at the rate of 10 per cent (Terengganu State Fatwa Committee). This rate is set at 10 per cent as the cost of irrigation applied by the authorities is not a burden to the farmers. Rental expenses on the agricultural land cannot be allowed.

However, this differs from the farmers in the state of Perlis. In Perlis, zakat is imposed on net revenue after deducting the production costs. The production costs include the rental of land, ploughing and planting, the price of fertilizers, pesticides, harvesting fee and the cost of transportation (Perlis State Shariah Committee). The irrigation cost is not allowed because it is used to determine the rate of zakat to be charged. Subsidies in any form cannot be treated as income from agriculture (Penang State Fatwa Committee).

\footnotetext{
${ }^{1}$ Reported from Jabir bin Zaid saying to men who owed which had been used for the needs of his family and his farm, he said: Ibn 'Abbas said deduct net debt (expenses) related to the farm, Ibn' Umar said: deducted the net debt (expenses) for the production costs and also for his family (Abu Ubyd, 2006: 424).

${ }^{2}$ Current assets are cash or other assets that are readily convertible to cash, which can be sold or used in the manufacture of goods for the longest period between one accounting year or one operating cycle such as accounts receivable, inventory and prepaid expenses. ${ }^{3}$ Working capital is current assets less current liabilities. Current liabilities are commitments that need to be settled in the longest period between one accounting period or one operating cycle.
} 
In general, the rate of zakat for agriculture is determined by the use of irrigation. For crops using irrigation without incurring any costs such as rain water, the rate of zakat is 10 per cent. For irrigated crops involving expensive costs, then the zakat rate is 5 per cent. For irrigated crops using paid irrigation at the rate of 50 per cent water and the other 50 per cent with rain water which incur expensive costs, then the rate of zakat is 7.5 per cent (JAWHAR, 2008).

\section{Sustainable Zakat Accounting and Scholars' Opinions In Malaysia}

Sustainable zakat accounting may or may not occur continuously, thus several questions about the ability of zakat accounting to change in accordance with the current needs and local circumstances have been raised to a few scholars of zakat in Malaysia. Three questions were posed. First, what is the argument in allowing a change in accounting zakat to be made? Second, what is the basis that can be used in the realization of a change in zakat accounting? Third, how to apply a method which can be used to implement a change in zakat accounting?

The selected scholars of zakat are divided into three categories. First, the jurists' category; ${ }^{1}$ second, the economists' category; ${ }^{2}$ and third, the zakat practitioners' category. ${ }^{3}$ Each category is represented by 4 scholars of zakat. The total number of scholars of zakat involved is 12 people. A questionnaire was distributed to each of the selected scholar.

In accordance with the questions asked, the analysis of the opinions of these scholars of zakat is divided into three sections. First, analyze the reasons for the changes in zakat accounting. The second section analyzes the basis of the change in zakat accounting. Third, analyze the method to these changes in zakat accounting. The opinions of the selected scholars of zakat in Malaysia pertaining to the changes in zakat accounting is summarized in Table 2 as follows:

Table 2: Opinion on Sustainable Zakat Accounting

\begin{tabular}{lllll}
\hline Basis & Jurists & Economists & Practitioners & Total \\
\hline Arguments for Sustainable Zakat Accounting & 3 & 3 & 4 & 10 \\
Basis of Sustainable Zakat Accounting & 2 & 4 & 4 & 10 \\
Basis for Sustainable Zakat Accounting Methods & 2 & 3 & 3 & 8 \\
\hline
\end{tabular}

\section{Arguments for Sustainable Zakat Accounting}

A review of previous studies shows that ijtihad has played an important role in the sustainability of zakat rulings. It occurs both during the time of Prophet (pbuh), the Companions and during the Tabi'in (successors of the Companions' time). Thus the sustainability of zakat rulings through ijtihad should be continued.

The majority of scholars of zakat were of the same opinion. Table 2 shows 10 scholars of zakat (83.3 per cent) agree that zakat accounting changes can be done through ijtihad. However according to them, the duty of zakat is qat'i (clear, unequivocal and fixed), while developments in its zakat accounting is ijtihadi. The changes can be made through several methods such as qiyas (analogy), maslahah mursalah (public good and benefit) and other fighiyah methods.

\footnotetext{
${ }^{1}$ They consist of the Director of the Islamic Academy (then), University of Malaya, Department Head of Sharia (at the time), Faculty of Islamic Studies, Universiti Kebangsaan Malaysia and two Mufti.

2 They consist of an economics professor, a professor of taxation and the two individual who have expertise in the field of Islamic finance in particular zakat.

${ }^{3}$ They consist of two zakat managers, two academicians who are directly involved with zakat accounting in Malaysia.
} 
In other words, although zakat accounting can be changed based on ijtihad, nonetheless the changes made must be allowed by the Islamic tenets and laws. That was emphasized by the scholars of zakat in Malaysia. It must take into account the purpose of nas (revealed text), whether the nas is based on the Qur'an or Prophet Muhammad (pbuh). 'Illah (the reason) behind any rulings on zakat reached must also be examined.

However, they argue that ijtihad is allowed on newly discovered assets such as shares, stocks and bonds. Various agricultural products that are not mentioned by the Hadith of Prophet Muhammad (pbuh), such as oil palm, rubber, coconut and others are also open to ijtihad. Thus for newly discovered property, ijtihad must be made immediately.

More specifically, they asserted that the party (or parties) making ijtihad must meet two main requirements before carrying out ijtihad. The first requirement is to understand the dalil (proofs) of al-Qur'an and the Sunnah in shaping the rules of law. The second condition is the understanding to Arabic language as used by the Arabic language experts. To enhance the decision made, a scholar suggested that the ijtihad is collectively reached either through an official dialogue, seminars, discussions and the like.

\section{Basis of Sustainable Zakat Accounting}

The basis for sustainable zakat accounting is due to word assets, wealth or property (al-Tawbah, 9:103) and the fruits (produce) thereof (al-Baqarah, 2: 267) itself. Assets and fruits (produce) thereof in which obligatory zakat is imposed upon are mentioned in the general sense. This is one of the main reasons that sustainable zakat accounting will continue to transpire throughout time.

This was agreed by majority of the scholars of zakat in Malaysia. Table 2 displays 10 of these scholars (83.3 per cent) agreed that the word assets and the fruits (produce) thereof mentioned in the Qur'an is in the general form (al-Tawbah, 9: 103; al-Baqarah, 2:267). One of the scholars of zakat said, in effect, the verses are exposed to changes in interpretation. In fact it opens the door for the jurists to study, analyze and then explore methods of zakat accounting. Thus, according to another scholar of zakat, the zakat accounting methods developed will take into consideration, current needs and local circumstances.

In understanding the general terms ascribed by the Qur'anic verses in question, the scholars suggested that reference need to be made to the Sunnah of Prophet Muhammad (pbuh), sirah (biography) of Prophet (pbuh), the practices of the Khulafa 'al-Rasyidun and the Companions. Another economist suggested that the meanings to zakat, sadaqah jariah (charitable alms), infaq (donations), qard al-hasan (benevolent loan) and others need to be studied in-depth. This study needs to be carried out so that the words could be construed in accordance with the word itself.

\section{Sustainable Zakat Accounting Methods}

In ensuring the continuity of sustainable zakat accounting, among the methods that can be employed is to find the illah as to why zakat itself is made compulsory. The jurists have agreed that a property will be imposed zakat if the asset has 'illah that grow or has growth potential. Growing can be defined as 'the ability to produce income or profit' (Yusuf al-Qaradawi, 1999). Apart from growing as an 'illah, there is also the view that richness (al-ghina) itself is the 'illah (Monzer Kahf, 1991).

The majority of scholars are of the opinion that illah can change. Table 2 shows eight scholars of zakat (66.7 percent) agreed with the statement. In addition, they also argued that there are similarities between growing as the 'illah with that of richness as the 'illah. This is because whoever owns the property that grows and exceeds a certain limit in which obligatory zakat is imposed, they are classified as rich or wealthy.

Even the current situation can also affect 'illah of the asset. According to them, if anyone has a lot of assets that are not growing such as copper money which is no longer valid, notwithstanding the amount in possession, he is not considered rich although copper itself has a price.

As such growing and wealth can be accepted as the property's 'illah in which obligatory zakat is imposed. Both the 'illah do not contradict each other. Upon application of the wealth as the 'illah is used, then the property in which zakat is imposed could be further broadened.

\section{Conclusion}


Zakat management of zakat institutions in Malaysia have from time to time made some appropriate changes in accordance with sustainable zakat accounting itself. It is so glaringly significant in zakat accounting for income, agriculture and business. Scholars of zakat in Malaysia are of the opinion that this can be realized because the fundamentals applied in the formation of zakat accounting for income, agricultures and business are general in form. They are of the view that through the application of qiyas for example zakat accounting can be modified in accordance with the current needs and local circumstances. Therefore it is appropriate that zakat institutions and scholars of zakat work together continuously so that sustainable zakat accounting can be realized at all times by taking into account current needs and local circumstances.

\section{Acknowledgement}

This article is part of the study on Perakaunan Zakat Pertanian Usahawan Tani di Malaysia (1001/PSOSIAL/816218) funded Research University Grat (RUI), Universiti Sains Malaysia (USM). The author wishes to express his appreciation to Ms Shereeza Mohamed Saniff for rendering her editorial services for this paper.

\section{Bibliography}

Abu Úbayd al-Qasim b. Salam. (2006). Kitab al-Amwal. (Noor Mohammad Ghiffari, Trans.). Islamabad: Pakistan Hijra Council.

'Ali Muhammad as-Sallabi, (2007). 'Umar Ibn al-Khattab, (Nasiruddin al-Khattab, Trans.), Vol. 1. Riyadh: International Islamic Publishing House.

Jabatan Kemajuan Islam Malaysia (JAKIM) (2001). Panduan Zakat di Malaysia. Kuala Lumpur: Jabatan Kemajuan Islam Malaysia.

Jabatan Wakaf, Zakat dan Haji (JAWHAR) (2008). Manual Pengurusan Pengiraan Zakat. Putrajaya: Jabatan Wakaf, Zakat dan Haji.

Mahmood Zuhdi Abd. Majid (2003). Pengurusan Zakat. Kuala Lumpur: Dewan Bahasa dan Pustaka.

Monzer Kahf (1991). Zakat: Unresolved Issues. In Development and Finance in Islam. AbulHasan Muhammad Sadeq, Ataul Huq Pramik and Nik Mustapha Nik Hassan (eds). Kuala Lumpur: International Islamic University Press.

Muhammad Abdul Mun'im Al-Jammal (2000). (Salahudin Abdullah, Transl.). Ensiklopedia Ekonomi Islam, Jld. I. Kuala Lumpur: Dewan Bahasa dan Pustaka.

Sanep Ahmad dan Hairunnizam Wahid (2003). Persepsi Terhadap Perluasan Sumber Zakat Harta Yang Diikhtilaf. In Prosiding Seminar Halatuju Zakat Korporat Di Alaf Baru. Kumpulan Kajian Zakat, Universiti Kebangsaan Malaysia Yusuf al-Qaradawi (1999). Fiqh az-Zakat: A Comparative Study. (Monzer Kahf, Transl.). London: Dar Al Taqwa Ltd. Zahri Hamat (2006). Perakaunan Zakat Pendapatan: Satu Kajian Semula. In Zakat: Pensyariatan, Perekonomian dan Perundangan, Abdul Ghafar Ismail and Hailani Muji Tahir (eds). Bangi: Universiti Kebangsaan Malaysia 